\title{
Diverse Students Can be Attracted to Geoscience
}

Suzanne O'Connell*, Martha Gilmore, Renee Johnson-Thornton, Tim Ku, Peter Patton, Phillip Resor, Dana Royer, Earth \& Environmental Sciences, Wesleyan University, Middletown, Connecticut 06459, USA

Many challenges facing humanity require geoscience expertise, yet the geoscientists addressing these challenges are predominantly white. More diversity in the profession is needed so that people with different ethnic and economic backgrounds may contribute to addressing geoscience challenges. Over the last 10 years, the geosciences have made substantial improvements in diversity (National Science Foundation, 2015), but we are far from parity with the U.S. population. However, in our department at Wesleyan University, visitors have commented on the diversity of our student body and ask how it was accomplished. Here we describe a 15 -year process of changes we have made that contribute to the increased diversity (Fig. 1). During this time, we modified our curriculum, increased our outreach to underrepresented minority (URM) students, hired new faculty, and increased faculty awareness of specific issues faced by URM students.

\section{CURRICULUM}

Many studies identify a college introductory course as an important factor in a student's decision to major in geoscience (e.g., Stokes et al., 2015). Our department teaches a variety of introductory courses to capture student interests. To complete the Earth and Environmental Sciences (E\&ES) major, a student then needs seven major-specific courses, two required seminars, and a year of at least two other science or math courses.

Our two required seminars are critical to the success of the major. They incorporate collaborative learning, peer-led team learning, and real-world problem solving, all of which have been shown to improve the retention of URM students (Conrad and Gasman, 2015).

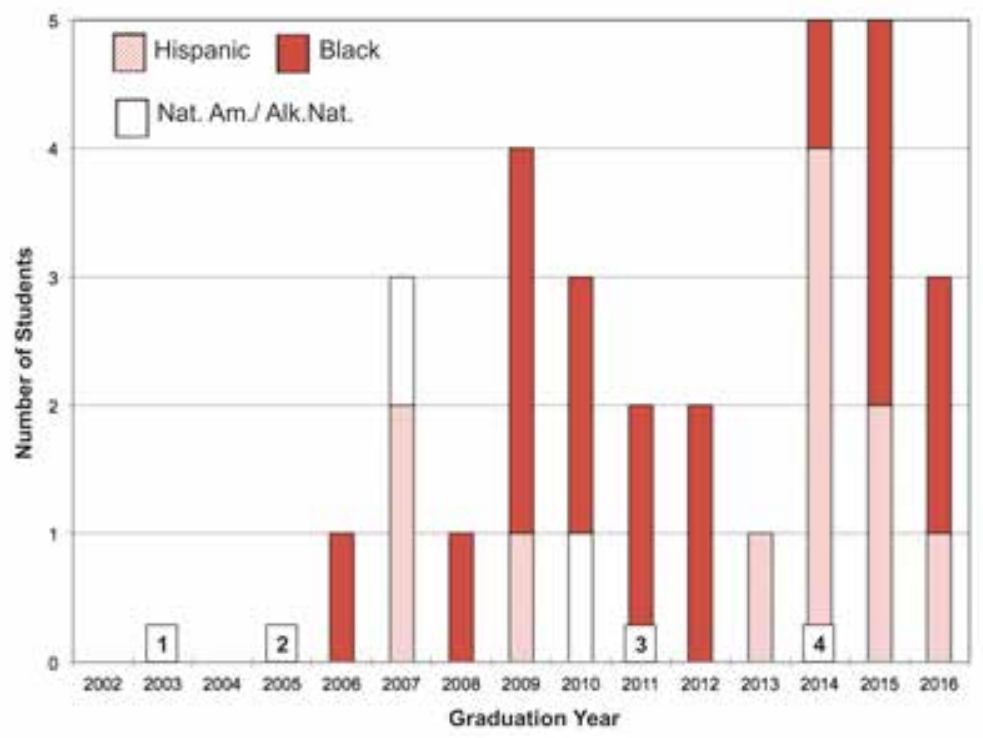

Figure 1. Student diversity by graduation year. Only the number students who identified as being from one of the NSF-defined diversity groups are shown on the $y$ axis. Numbers for students who identified as white, mixed race, Asian, or unknown are not included. Numbers on the $x$ axis refer to departmental changes: 1-hired Asian-American professor; 2-started senior seminar; 3-started sophomore seminar; 4-hired Hispanic professor. Tenure-track faculty composition, 2001-2002: two women (1 white, 1 black) and four men (all white); 2015-2016: 2 women (1 white, 1 black) and 6.5 (half appointment in another dept.) men (4.5 white, 1 Asian, 1 Hispanic). Number of graduates varies from 8 (2004) to 24 (2015). Nat. Am.-Native American; Alk. Nat.-Alaska Native.

During sophomore seminar, students explore Connecticut's geologic evolution. This pass/fail seminar provides students with a common background and develops a sense of community-another contributor to persistence in the major (Callahan et al., 2015).

Senior seminar lasts two semesters with a January field trip. During the fall, seniors read primary literature and collaboratively develop field-based research projects. They plan, write about, and present proposed fieldwork. In the spring, students analyze their samples and present their work at a public symposium, which will be compiled into a written report. Because of this experience, we are confident that our graduates can comprehend original literature, define a problem, conduct research, and develop excellent oral and written communication skills.

\section{STUDENT OUTREACH}

Geoscience suffers from a poor perception among students interested in helping the environment or society, finding a job, and making money (e.g., Hoisch and Bowie, 2010; Sherman-Morris and McNeal, 2016). Therefore, our faculty try to serve as ambassadors for the discipline both in and out of the classroom.

Student advising is important. Many E\&ES faculty ask to be advisers for incoming URM students with an interest in science, thus gaining an opportunity to inform them about geoscience's positive aspects. Many URM students are also the first-generation (FG) of their family to 
attend college. FG students and their parents are more likely to be interested in career opportunities (Engle et al., 2006). The geosciences are well-positioned to exploit this interest. The Bureau of Labor Statistics (2015) predicts that geoscience jobs will grow 10\% from 2014 to 2024 . Advisers and department websites can provide career information for both students and their parents.

Inviting URM geoscientists to speak and to meet with students is another great opportunity to provide role models. Any seminar is an opportunity to engage URM students. FG and URM students, in particular, need to know that URM faculty are part of a learning community.

\section{FACULTY AWARENESS}

Faculty who understand different students' backgrounds can design a pathway for success for all students. Multiple studies have identified barriers to URM and FG students' integration into college. They are less likely to feel that they fit in, possibly not as academically well prepared (ACT/COE, 2016), and less likely to seek out a professor for help (Kuh et al., 2006). This leads them to doubt their ability to succeed in college, and especially in science (e.g., MacPhee et al., 2013). We find that professors need to initiate relationships with these students.

Faculty can invite students from an introductory class to lunch or coffee and include an upper-level student. This is an opportunity to begin to develop a relationship and for students to find out about each other, the major, and geoscience. In the E\&ES department, URM students are offered part-time lab-research jobs and, if possible, a summer research experience.

In a research lab, students interact with and establish a relationship with faculty and upper-level students, becoming comfortable in a research environment. Being selected to work in a lab may also build student confidence. URM and FG students are likely to have friends with similar backgrounds, providing more engagement opportunities.

A barrier to reaching out to URM students may be faculty's implicit associations, preconceived ideas, and responses about who is best-suited to a science career (Banaji and Greenwald, 2013). Stereotype threat impedes students' success. This occurs when people internalize the negative associations about their group and do not perform up to their capabilities (Steele, 2011). Stereotype threat increases as the difficulty of academic work increases, when the activity (e.g., test) is considered evaluative of mental ability, and in larger school settings, where anonymity exacerbates concerns about belonging. Several stereotype threat interventions have been identified (Walton and Cohen, 2011). Imposter syndrome, the feeling of being a fraud despite a record of high achievement, can also impede students' progress.

The following are some actions we have taken that have helped diversify our department:

1. Visit and give presentations about geoscience to campus organizations that have a high percentage of diverse students.

2. Create a learning community in your classroom with non-competitive environments where students can interact with peers. This helps to counteract stereotype threat and imposter syndrome.

3. Reach out to involve URM students. Let them know you have absolute confidence that they will succeed in your class. Invite them to work in your lab.

4. Find research and experiential programs for URM students, both on and off campus (e.g., GeoCorps ${ }^{\mathrm{TM}}$ America and NSF research experiences for undergraduates).

5. Connect URM students with organizations that focus on minorities in geoscience, such as the National Association of Black Geologists and Geophysicists, Pathways to Science, and the Society for Advancement of Chicanos/ Hispanics and Native Americans in Science (SACNAS). Encourage them to apply for On To the Future (OTF) funds to attend a GSA Annual Meeting.

6. Include diverse speakers in your seminar series, and encourage them to meet with students.

7. Stay in touch with the students. Send them information about jobs and graduate school opportunities. Offer to write letters of reference.

8. Find out what helped URM students succeed at your institution and do more of it.

9. Don't get discouraged.

\section{REFERENCES CITED}

ACT/COE (Council for Opportunity in Education), 2016, The Condition of College \& Career Readiness, First-Generation Students: ACT/ COE, 20 p., http://www.act.org/content/dam/act/ unsecured/documents/CCCR_National_2016.pdf (last accessed 6 Dec. 2016).

Banaji, M., and Greenwald, A., 2013, Blind Spot: New York, Delacorte Press, 272 p.

Bureau of Labor Statistics, 2015, Occupational Outlook Handbook, Geoscientists: U.S. Department of Labor, http://www.bls.gov/ooh/ life-physical-and-social-science/geoscientists.htm (last accessed 29 Nov. 2016).

Callahan, C.N., Libarkin, J.C., McCallum, C.M., and Atchison, C.L., 2015, Using the lens of social capital to understand diversity in the earth sciences workforce: Journal of Geoscience Education, v. 63, p. 98-104, doi: 10.5408/15-083.1.

Conrad, C., and Gasman, M., 2015, Educating a Diverse Nation: Harvard University Press, 320 p.

Engle, J., Bermeo, A., and O'Brien, C., 2006, Straight from the Source: What Works for First Generation College Students: Washington, D.C., Pell Institute for the Study of Opportunity in Higher Education, 46 p.

Hoisch, T.D., and Bowie, J.I., 2010, Assessing factors that influence the recruitment of majors from introductory geology classes at Northern Arizona University: Journal of Geoscience Education, v. 58, p. 166-176, doi:10.5408/ 1.3544297.

Kuh, G.D., Kinzie, J., Buckley, J.A., Bridges, B.K. and Hayek, J.C., 2006, What Matters to Student Success: A Review of the Literature: National Postsecondary Education Cooperative, $151 \mathrm{p}$.

MacPhee, D., Farro, S., and Canetto, S.S., 2013, Academic self-efficacy and performance of underrepresented STEM majors: Gender, ethnic, and social class patterns: Analyses of Social Issues and Public Policy, v. 13, p. 347-369, doi: 10.1111/asap.12033.

National Science Foundation, 2015, Women, Minorities, and Persons with Disabilities in STEM: Arlington, Virginia, National Science Foundation Special Report NSF 15-311, https:// www.nsf.gov/statistics/2015/nsf15311/start.cfm (last accessed 29 Nov. 2016).

Sherman-Morris, K., and McNeal, K.S., 2016, Understanding perceptions of the geosciences among minority and nonminority undergraduate students: Journal of Geoscience Education, v. 64, p. 147-156, doi: 10.5408/15-112.1.

Steele, C.M., 2011, Whistling Vivaldi: W.W. Norton \& Company, $256 \mathrm{p}$.

Stokes, P.J., Levine, R., and Flessa, K.W., 2015, Choosing the geoscience major: Journal of Geoscience Education, v. 63, p. 250-263, doi: 10.5408/14-038.1.

Walton, G.M., and Cohen, G.L., 2011, A brief social-belonging intervention improves academic and health outcomes of minority students: Science, v. 331, p. 1447-1451, doi: 10.1126/ science. 1198364 .

Manuscript Received 10 Feb. 2016 REVised MANUSCRIPT RECEIVED 30 Aug. 2016 ManusCript aCCEPTEd 22 SEPt. 2016 